\title{
Articles
}

\section{Working with the President: Extension and Continuing Education at UBC, 1935-1983}

Scott McLean, University of Calgary

\section{AcKNOWLedgMent}

Research for this article was supported by a Standard Research Grant from the Social Sciences and Humanities Research Council of Canada.

\begin{abstract}
Leaders of university continuing education units frequently dedicate significant energy to managing relationships between their units and senior university administrators. Many CJUCE readers know of cases where a particularly sympathetic (or unsympathetic) university president or provost has substantially changed the trajectory of a continuing education unit. Using historical documents from the University of British Columbia, the author of this article constructs a case study of the influence of presidential support on the philosophy and practice of
\end{abstract}

RÉSUMÉ
Les chefs des unités d'éducation
permanente universitaire dépen-
sent souvent beaucoup d'énergie à
la gestion des relations entre leurs
unités et les gestionnaires princi-
paux des universités. Beaucoup de
lecteurs de la Revue canadienne
de l'éducation permanente uni-
versitaire sont au courant de cas
où une présidence ou un doyen
particulièrement sympathique (ou
non sympathique) de l'université a
beaucoup changé la direction d'une
unité d'éducation permanente. À
l'aide de documents historiques
de l'Université de la Colombie-


university extension and continuing education. In short, UBC's Extension department emerged and flourished under the leadership of two long-serving presidents who expressed significant support for its function as a primary role of the university. In the 1960s, following the appointment of a president who considered research and degreecredit teaching to be the university's distinctive mission, the department experienced a crisis. However, the period following 1975 brought renewed executive support when a new president with an expansive vision of the contribution that the university should make to society was appointed. This article not only presents an interesting historical case study but also provokes reflection on how contemporary leaders in continuing education can nurture support from senior administrators.
Britannique, l'auteur de cet article développe une étude de cas sur l'influence de l'appui de la présidence sur la philosophie et la pratique de l'éducation permanente universitaire et des programmes universitaires d'extension. Bref, le département d'extension de l'Université de la Colombie-Britannique a été développé et s'est épanoui sous le leadership de deux présidences de longue durée qui démontraient un appui considérable envers sa fonction de rôle principal de l'université. Au cours des années 1960, suivant la nomination d'une présidence qui considérait que la recherche et l'enseignement par crédits vers l'obtention du diplôme étaient la mission distincte de l'université, le département subit une crise. Cependant, la période suivant l'année 1975 connu de nouveau de l'appui de la part de l'administration avec la nomination d'une nouvelle présidence avec une vision plus large de la contribution que l'université devrait faire à la société. Cet article présente non seulement une étude de cas historique intéressante, mais suscite aussi une réflexion sur la façon dont les chefs contemporains en éducation permanente peuvent encourager l'appui des administrateurs principaux. 


\section{INTRODUCTION}

The University of British Columbia (UBC) was founded in 1908, when the Provincial Legislature passed An Act to Establish and Incorporate a University for the Province of British Columbia. UBC opened its doors in September 1915, with a total of 379 students enrolled in three faculties: Arts and Science, Applied Science, and Agriculture. From the beginning, providing education to people other than its "regular" students was a significant priority for the university. The university calendar for 1915-16 explained its three interrelated goals:

The Province, through the University, undertakes to furnish instruction in the various branches requisite for a liberal education, and in the technical branches that have a bearing upon the life and industries of the Province. It will aim to encourage research work in all departments, to produce creative scholars, and so do its share in enlarging the domain of knowledge. It is the intention to organize an extension division, upon a broad basis, to assist the people of the Province to assimilate the useful knowledge so rapidly advancing, and to carry it to those whose circumstances deprive them of the opportunity of attendance within its walls. (University of British Columbia, 1915, p. 22)

From its establishment, teaching, research, and extension work were considered to be the primary functions of the university. The relative importance placed upon these three functions has varied over time, reflecting social and institutional changes, as well as the distinctive visions and priorities of respective university presidents.

This article contributes to the historical literature on university extension and continuing education in Canada (Alexander, 1997; Clark, 1985; Corbett, 1952; Cormack, 1981; Kidd, 1956; McLean, 2007a, 2007b, 2008; Paul, 1979; Selman, 1966, 1988; Welton, 2003). While these and other historical studies narrate the evolution of extension and continuing education at Canadian universities, the specific focus of this article - the relationship between university presidents and continuing education units - has been the stuff of "legend and lore," rather than the subject of scholarly research. Leaders of university continuing education units frequently dedicate significant energy to managing relationships with senior administrators. Indeed, many CJUCE readers know of cases where a particularly sympathetic (or unsympathetic) president or provost has substantially changed the trajectory of a continuing education unit. However, few, if any, published studies have carefully analyzed how the evolution of university extension and continuing education has reflected, or been reflected in, public statements made by university presidents. 
To that end, historical documents from UBC have been used here to construct a case study of the influence of presidential support on the philosophy and practice of university extension and continuing education. The research methods were simple: annual reports from presidents and directors of extension or continuing education were gathered from the UBC archives. Reports of UBC presidents were available from 1929 through 1983; annual reports from the Department of University Extension or the Centre for Continuing Education were available from 1937 through 1979. From these documents, those passages expressing either a president's views on extension or continuing education or a director's views on the philosophy and practice of extension or continuing education were extracted. References to these reports are given in the text, with a page number, in square brackets, following the quotation. References to other archival documents are cited with a source identified in the list of references.

This case study focuses on the work of several key figures in the history of UBC. The key presidents (with their dates of service indicated in parentheses) are Leonard Klinck (1919-1944), Norman MacKenzie (1944-1962), John Macdonald (1962-1967), and Douglas Kenny (1975-1983); the key directors of extension and continuing education are Gordon Shrum (1937-1953), John Friesen (1953-1966), Gordon Selman (1967-1974), and Jindra Kulich (1974 to the late 1980s). The article describes how the UBC Department of University Extension emerged and flourished under both President Klinck and President MacKenzie, each of whom expressed tremendous support for extension work. The department experienced a crisis in the 1960s, when President Macdonald encouraged UBC to focus on research and degreecredit teaching at professional and graduate levels, but enjoyed renewed support under President Kenny, who again extolled the virtues of university continuing education in the relationship between UBC and society. The article narrates the evolution of the discourse of successive presidents and directors of extension and continuing education and concludes with some reflections about what contemporary leaders in continuing education can learn from this case study.

It is important to note that the institutional and social context of extension and continuing education changed dramatically at UBC between the 1930s and the 1970s. Although a comprehensive review is beyond the scope of this article, the significance of these changes can be seen in three brief examples. First, the population of the province, and the proportion of that population living in urban areas, grew substantially. From 1941 to 1971, the population nearly tripled, from just over 800,000 to just under 2.2 million; in the same period, the proportion of the population residing in rural areas declined by about half, from $46 \%$ to $24 \%$ (Canada, Dominion Bureau of Statistics [DBS], 1941; Statistics Canada, 1971). Second, the way that people made a living changed significantly. In 1941, nearly $33 \%$ of men in the province worked 
in agriculture, and a further $6 \%$ of them worked in forestry, mining, or fisheries. By 1971, the proportion of men engaged in primary industries had fallen to less than 10\%. From 1951 to 1971, the proportion of women engaged in the labour force increased from 23\% to 40\% (Canada, DBS, 1941, 1951; Statistics Canada, 1971). Third, partly in response to demographic and economic change, the province's post-secondary education system was transformed during these decades (Association of Universities and Colleges of Canada [AUCC], 2009). Until 1960, UBC had a virtual monopoly on university education in the province, with Victoria College and the Vancouver School of Art serving other post-secondary needs. In the 1960s and 1970s, two new universities and half a dozen colleges were established in the province. UBC itself grew dramatically in both size and functions. In 1935, there were about 2,000 students; by 1975, there were about 24,000 (UBC, 2009). Research activities, along with professional and graduate education, expanded significantly. The writings of the university presidents and extension directors must be understood within this evolving institutional and social context, since the discourse and practice of university continuing education changed in part because of this changing context and in part because of the distinctive attitudes and leadership of presidents and directors. Although this article focuses on the words of the leaders involved, their words were shaped by social and institutional forces that are not fully analyzed here.

\section{The Case Study}

As noted earlier, UBC expressed a commitment to extension work in its very first official calendar. The university established a University Extension Committee in 1918, and during the 1920s, this committee organized an average of nearly 200 public lectures by UBC faculty members each year. These lectures, which were organized in collaboration with community-based organizations in the greater Vancouver area, as well as in cities and towns on Vancouver Island and in the Fraser Valley and the Okanagan Valley, attracted an average aggregate attendance of about 20,000 people each year. In the early 1930s, with the onset of the Great Depression, the UBC budget was reduced considerably, and extension lectures outside the Vancouver area declined substantially.

\section{Establishing the Department of University Extension: Klinck and Shrum}

Although the Great Depression initially hampered the extension work of UBC, it eventually led to its increasing involvement in such work. In the fall of 1933, the Carnegie Corporation of New York granted \$50,000 to each 
of the four provincial universities in Western Canada, for what President Klinck described as "projects designed to improve the morale of the professorial staff and to extend the usefulness of the institution." By 1935, Klinck had committed to investing $\$ 30,000$ of this grant to establishing a Department of University Extension. On November 16 of that year, he outlined his plans to the Vancouver Institute in an address entitled A Plan for Adult Education in British Columbia (Klinck, 1935). Klinck began his speech by asserting that the emerging field of adult education was one of growing importance. He defined adult education as involving elements of personal growth, vocational preparation, and citizenship development, and described the development of adult education in England, the United States, and Canada. He then summarized the debate regarding the suitability of adult education to the mission of universities:

Whatever else may be said regarding the universities' off-campus service to adults, practically all the universities have accepted and are attempting to discharge the responsibility with all the effectiveness at their command, and they are unabashed and unapologetic in doing so. Moreover, instead of decreasing their contacts with their extra-mural constituents, they propose to increase them, and thus help provide enlarged opportunities for intellectual service to every class or group not served by other agencies. Whatever is the attitude of the University of British Columbia on this question, the fact remains that University Extension is alive and in active operation from one end of the Dominion to the other. (pp. 9-10)

To exemplify his claims regarding the growing importance of adult education, Klinck described the extension work of St. Francis Xavier University and the University of Alberta. Following this description of the field, Klinck described his plans for developing adult education at UBC. He acknowledged that adult education had previously constituted "a very minor part" of UBC policy and outlined the work of the University Extension Committee. For the future, Klinck indicated that UBC would establish a Department of University Extension whose staff would "meet the majority of requests for extra-mural instruction" so that additional teaching loads would not be imposed upon the professorial staff (p. 16). As for the "Purpose of the New Organization," he noted the following:

The University has no desire to create a super-organization, or to impose itself upon any established effort. Rather, its chief purpose is to promote and strengthen whatever is already in the field. It is interested in supplying, not necessarily what it wishes the times demanded, but what is actually demanded. It is prepared to co-operate, to the limit of its resources, with any institution, public or private, scholastic or 
non-scholastic, which has an educational program for adults, excepting those agencies which have as their purpose the propagation of doctrines. (p. 16)

Klinck's plan set an ambitious agenda for UBC and broadened the scope of the university's extension mandate far beyond the provision of offcampus lectures. To pursue this mandate, UBC established a Department of University Extension, which became operational in 1936.

In his annual report for 1937-38, the director of the Extension department, Gordon Shrum, reflected President Klinck's focus on the provision of adult educational services:

A study of this report will indicate that during the past year the University has made a real effort to provide in some measure the opportunities whereby adults in even the remotest sections of the Province may keep in contact with the arts, with natural and social science, with political and economic developments, and, in short, with the life and thought of their provincial University. As a result, the University is becoming firmly established as the centre of the cultural life of the Province. (p. 1)

In this, and subsequent annual reports, Shrum claimed that extension work was mutually beneficial for UBC and the people of British Columbiathe people needed adult education and the university needed public support. Shrum's reports during Klinck's tenure as president consistently referred to the growing number of people taking part in extension programs and to the public relations benefits realized by the university as a result. As one example, Shrum opened his 1941-42 report with the observation that "a considerable development and expansion of the work of the Department of University Extension has occurred during the year under review" (p. 1) and concluded the report with the claim that "it is safe to say that the standing of the University in the community has been very greatly enhanced as a result of its policy of placing its resources at the service of the public through an adult education programme" (p. 12).

In his annual report for 1944-45, Shrum again reflected upon the expansion of extension activities at UBC, claiming that

the Extension Department can measure its success only in terms of the effectiveness with which it helps to make the University a people's institution, a source to which the citizens of this province can turn for information and inspiration, with the knowledge that their needs are considered as important as those of the students on the University Campus. (p. 1) 
UBC extension programs in the 1940s and 1950s were of three main types. First, through organizing public lectures, radio broadcasts, slide shows, motion pictures, and the circulation of library resources, the Extension department provided educational services to massive numbers of adults. Second, through non-credit evening classes, vocational programming specific to industries such as agriculture and fishing, and professionally oriented conferences and summer institutes, UBC had an even-more intensive impact on several thousand adults each year. Third, through organizing hundreds of local study groups across British Columbia, either independently or in collaboration with national radio programming, University Extension organized an ambitious set of citizenship and public affairs programs.

\section{Defining the Role of Extension in the University and Society: MacKenzie and Friesen}

The mutual benefits, to university and community, reported annually by Shrum throughout the 1940s, were also underlined in President Norman MacKenzie's initial reports. In his 1946-47 report, Mackenzie wrote

A logical conclusion, based on this year's increased Extension activity, is that more and more British Columbians are finding adult education necessary either as vocational training or as an enriching influence in their cultural life. In this process of reinforcing practical experience with systematic education, the Extension Department looks forward to years of normal growth in an ever-widening area of service. (p. 19)

The following year, Mackenzie described the benefits to UBC of providing service to the provincial community:

It is my wish - a wish shared by all members of the University - that every person in this province should be fully aware of the University's capacity to serve them. Our outlook is entirely practical: we are a part of the communities to which we look for support and we feel that such support should be forthcoming in return for services rendered. (p. 25)

Throughout his reports in the 1940s and 1950s, MacKenzie consistently highlighted the role of the Department of University Extension in mobilizing the resources of the university for the benefit of communities throughout British Columbia.

Whereas Klinck and Shrum established the UBC discourse of extension and its mutually beneficial impacts on university and community, MacKenzie and Friesen transformed this discourse into a more modern expression of the contributions of the university to adults' lifelong learning needs. MacKenzie dedicated his 1952-53 president's report to an extended 
discussion of the extension function of universities. He began by describing the traditional university functions of research and teaching:

There are those who take the view that the primary purpose of a University is to discover new knowledge. Those who do so very naturally stress the research function. There are also those who feel that the University must first of all be concerned with the preservation and perpetuation of the cultural inheritance of the past. These tend to stress the teaching function. There are still others who point out that the first universities were in large measure professional training schools and that a primary purpose of all universities will always be that of supplying the more complicated kinds of technical and professional skill which society needs. These tend to stress the practical aspects of learning ... (p. 1)

He went on to assert that there was "another primary function of universities in our kind of society," labelled this function "university extension," and indicated there were people who had "reservations" about the involvement of the university in this function. In the face of these expressed doubts regarding the value of extension work at universities, MacKenzie argued:

To me the issue is perfectly clear. If we are to have and maintain a society in which every adult citizen is called upon to have opinions and vote on matters not only of local but of national and international importance ... some agencies must exist or be created to try to develop and obtain as great an understanding of the problems and nature of citizenship -in its broadest sense-as is possible. Also if we are to continue to live in a complex technological world that is changing and developing rapidly, we must have agencies to help keep the adult population informed about the changing world and the implications of those changes both for their lives and livelihood. And finally, if we are to enjoy the real benefits of technological development, we must help multiply the opportunities for self development and individual satisfaction in the leisure time technology has made possible. (p. 3)

MacKenzie continued his report with an explanation of the importance of adult education for the purposes of nurturing active and responsible citizens, developing workers' vocational and professional capacities, and providing the opportunity for cultural enrichment. He further argued that no other public institutions existed with the expertise and capacity to undertake this work, claiming that "there is no way that the universities can avoid trying to meet this new demand, even if they wanted to. The community services rendered by the Department of University Extension are not only here to stay but are likely to increase markedly" (p. 5). MacKenzie concluded by observing that to meet the increasing demands for such services, the 
Extension department would require increases to its staffing complement and budget allocation.

During the 1952-53 academic term, MacKenzie claimed that rapid social change was creating a need for ongoing adult education and that universities had a special responsibility to respond to this need through extension activities. These claims were developed eloquently by John Friesen, who arrived as the director of University Extension in 1953. In his annual report for 1956-57, Friesen used the term "lifelong learning" to link these claims:

No longer, on any basis whatsoever, can adult education be seen as confined to remedying deficiencies in the education of the young. It now exists in its own right with its own task of serving a population that feels more and more the need for lifelong learning. What a few Canadians of vision and courage have repeatedly stressed, recent world events are proving with impelling urgency; namely, that our future will be determined in very large measure by the emphasis we choose to place on public education for children, youth and adults. (p. 28)

By the mid-1950s, Friesen and MacKenzie were making the argument, familiar to current CJUCE readers, that citizens needed lifelong learning to keep up with changes in society and that nations needed lifelong learning to maintain a competitive position in the world.

Although Friesen's discourse was distinct from that of Klinck and Shrum, he maintained a programmatic focus on the three pillars of adult education that Klinck had defined in 1935. In his annual report for 1964-65, Friesen wrote

What are the concerns of adults for further education? We submit that they are threefold: to make a living, to enrich experience and purpose in life, and to participate actively in citizen affairs. University Extension interprets these areas as civic, liberal, and professional education. (p. 5)

In addition to maintaining a substantive focus on a broad range of adult educational activities, Friesen continued to consistently report, as Shrum had before him, the significant and growing demand for extension programs from people across British Columbia. In one example from his 1955-56 report, Friesen argued that the growing numbers of participants in extension programs was "proof that the goal of the people's university is being realized" and that UBC was "more than ever before" bringing "the maximum of its rich resources into the shops, the farms, the schools, the fishing villages where people live, work, and play" (p. 4). 


\section{Contesting Resources and Relevance: Macdonald and Selman}

Just as the rise of the UBC Department of University Extension was guided by President Klinck's Plan for Adult Education in British Columbia, so too the fall of that department was influenced by another president's ambitious plan. In 1962, John Macdonald became president and promptly set to work writing, publishing, and having the provincial government adopt the main recommendations of his 1962 report entitled Higher Education in British Columbia and a Plan for the Future. Known as the Macdonald Report, it documented the history of higher education in British Columbia, outlined the growing importance of higher education in the world, and proposed the establishment of colleges and other post-secondary institutions across the province (Macdonald, 1962). In his 1962-63 president's report, Macdonald outlined the implications of his plan for UBC:

No longer is this University responsible for all higher education; no longer is this University faced by the necessity for unlimited growth. The University has now an opportunity to define more precisely the role that it should play in the province's educational system. The University will continue to offer undergraduate education. Indeed, for a few years, until other institutions are in a position to assist, the numbers enrolled in undergraduate education will continue to increase. Nevertheless, a limit can at last be foreseen. Simultaneously, the University will need to strengthen and enlarge its graduate programme; and it will be responsible for virtually all professional education in British Columbia. (p. 13)

The historical mission of UBC in the provision of adult education was notably absent from Macdonald's focus on graduate and professional education.In his annual report for 1963-64, Macdonald explicitly argued that universities should not engage in too broad a range of activities. Upon asking, "Is there any predictable limit to the interests and functions of ... the University of British Columbia?" he replied that his "own conviction is that there are limits, and that these should be related to the central purposes of a university, the qualities that distinguish a university from all other institutions" (p. 9). He defined these central purposes in terms of the "fostering of a permanent spirit of inquiry and creativity, the engendering of powers of sound judgement, and the developing of the cultural resources of society" (p. 9), going on to distinguish between professions and vocations and to argue that vocational instruction was not appropriate to universities. Macdonald clearly believed that UBC should not engage in general forms of adult education and community service:

Universities are often called upon to engage in activities that in the judgement of most educated people lack the essential characteristics that would justify their inclusion in a university; the reader will have 
no trouble in thinking of illustrations. Frequently these pressures are the result of genuine needs in a community and the only question that demands an answer is whether they should be provided by the university or by some other institution. The late Sidney Smith, President of the University of Toronto, offered as a negative rule of thumb the principle that a university should engage only in those activities that no other institution can perform so well. (pp. 9-10)

There is no doubt that Macdonald's plan for higher education in British Columbia set extension work at UBC on a very different trajectory from that established by presidents Klinck and MacKenzie. In his annual report for 1963-64, University Extension director John Friesen described a reduction in the range of his department's activity in adult education:

In the year under review in this Report, the Extension Department's programme has been strongly influenced by two major policy changes in the University. The creation of new universities in the province and the increased emphasis at the University of British Columbia on graduate work and professional training have accelerated the trend within the Extension programme to focus to a greater extent on professional and liberal education courses for the university graduate. In addition, the decision by the Board of Governors that the Extension programme must become substantially more self-supporting has made necessary both a revision of the Department's fee structure and the elimination or curtailment of some important aspects of the programme. (p. 2)

Specifically, Friesen argued that fiscal constraint would lead to the relative decline of liberal education in comparison to professional and technical studies. Although for nearly three decades the Extension department had promoted a balance between civic, liberal, and professional education, changes sparked by the Macdonald Report led the department to increasingly focus on continuing professional education and part-time, degreecredit studies.

Themes of budgetary pressure and a narrowing of educational provision were prominent in the annual reports submitted by Gordon Selman in his role as director of Extension. In his 1967-68 report, Selman wrote

We take considerable satisfaction in the overall growth of the program and in the rapid expansion of continuing education in the professions. The need for general or liberal education in our society, however, is greater than ever, not less, and it is to be regretted that financial pressures on the Department's program have forced us to decrease the staff time we can devote to these broad and basic fields. These financial restrictions on the program continue to represent the single most limiting factor on the growth and balance of the University's Extension activities. (p. 5) 
The following year, Selman's report expressed an even stronger sense of frustration:

It was disturbing that although the year could fairly be described as outstandingly successful in terms of many of the programs offered and the overall enrolment figures, the financial outcomes did not measure up to the University's expectations. This was further evidence that the Extension Department is being required to operate under too heavy financial pressure ... (p. 6)

In 1969, UBC appointed a Senate Committee on Continuing Education to review and make recommendations on the university's policy framework for extension and continuing education. In 1970, the work of this committee resulted in the transformation of the Department of University Extension into the Centre for Continuing Education and in the encouragement of professional faculties to operate their own independent continuing education programs. In his 1969-70 report, President Walter Gage explained that "the new name means that UBC as an institution will place greater emphasis on the continuing education of graduates and education at an advanced level" (p. 28).

In the early 1970s, Selman, then serving as director of Continuing Education, submitted annual reports that focused on part-time, degreecredit studies and on the constant struggle for resources and recognition for non-credit programming. Selman dedicated the entire Director's Foreword in his 1971-72 annual report to explaining the importance and advocating the expansion of part-time, degree-credit study. He concluded that foreword as follows:

The community is looking to U.B.C. at the present time to provide greater access to degree study for adults. In doing so, the university will not only be providing a much-needed additional service, it will also gain greatly in the eyes of the people of the province. If the university does not respond with some vigorous new initiatives in this area, it will, I am afraid, suffer unwanted criticism from other sections of the educational community and from many interested members of the general public as well. It would also be in danger of losing its hard-earned and much cherished position of leadership in providing educational opportunities for the adult citizens of the province. (p. 6)

Selman thus linked the traditional extension mandate of community service and adult education with the increasing institutional focus on advanced education and the provision of programs that could not be duplicated by other post-secondary institutions.

In addition to lobbying for increased opportunities for part-time, degreecredit study, Selman's reports lamented the marginal position of continuing 
education at UBC. In his 1972-73 annual report, Selman argued that in the field of non-credit programming, "UBC's continuing education activities have a reputation second to none among the universities in Canada and each year many visitors from home and abroad visit our Centre to discuss our curriculum, methods, and organization" (p. 2). Despite praising the excellence of the work of his staff, Selman identified several "unresolved problems" facing the Centre for Continuing Education (pp. 3-5). He indicated that pressures for financial cost recovery were making it difficult to engage in non-credit programming that related to civic or liberal education, that was innovative or experimental in nature, or that served low-income people or those living outside of Greater Vancouver. He lamented that some faculty members had a dismissive attitude toward non-credit programming. Finally, he indicated that UBC was still determining the ideal nature of its relationships with other providers of adult education in the province and that it was not always easy to define the boundaries of "university level" educational programming. In his final annual report as director (1973-74), Selman stated forcefully

I believe there must be a stronger institutional commitment to continuing education as a function of the University. At the present time, the importance of continuing education is becoming more widely recognized on every hand and every major report on the future development of education lays stress on the need for all our public educational institutions to play a more active role in that field .... The contrast between University financing of this work and the community's expectation of us is a glaring fact .... The treatment of continuing education as a marginal, low-priority activity is not in keeping with our traditions as an institution and more important, in the changed conditions of today's world, is in my view not an acceptable policy for a public University. (p. 1)

\section{A Renaissance of Continuing Education: Kenny and Kulich}

Selman's hopes for greater institutional recognition of continuing education were reflected in the writing of Douglas Kenny, who took up the post of UBC president one year after Selman left the Centre for Continuing Education. In his first report, for 1975-76, Kenny announced a clear reversal of the trajectory for extension work established by John Macdonald in 1962. He wrote that "no university will be highly regarded unless it shows a willingness to place its resources at the disposal of the community" and reported that the Centre for Continuing Education,

with the strong support of the University administration, has initiated an important move back towards serving more fully individuals 
throughout the province, a type of community education which it had unfortunately withdrawn from some ten years ago. It is our aim to expand this service to other areas of the province as fast as it is financially feasible. (p. 10)

In his president's reports from 1975-76 through 1982-83, Kenny consistently highlighted continuing education, along with teaching and research, as a core function of UBC. His continuing education reports highlighted the work of the Centre for Continuing Education and reported statistical summaries of the participation of tens of thousands of British Columbians in the programs of the Centre and those organized by faculties in fields such as health sciences, commerce, social work, agriculture, education, and forestry.

In his 1978-79 report, Kenny celebrated the history of continuing education at UBC and linked the expansion of it to social change:

One of the most impressive developments that has taken place at UBC in the post-World War II period has been the growth of continuing education programs sponsored by the University in all parts of the province. Our Centre for Continuing Education has a proud history extending back into the 1930s of providing outreach programs that extended to the very boundaries of the province. With the growth of professional schools and the increased demand for general and specialist education, the University has done everything it could to respond to the needs of professional organizations and the expressed needs of the public at large. I think it is safe to say that there is scarcely a single faculty, school or department in the University that is not somehow involved in general and specialist continuing education for our citizens. The breadth and depth of our continuing education programs reflects the rapidly changing world in which we live. The revolution in communications, the growth of the women's movement, the incredible increase in the rate at which new knowledge accumulates, the desire of our citizens to improve themselves intellectually and economically, the increased amount of leisure time that is available to people-all these factors have contributed to the expansion of continuing education programs offered by the University. (p. 23)

In his final report (1982-83), Kenny expressed pride in the claim that UBC promoted "one of the most extensive university continuing education programs anywhere in the world," and he argued that in the coming decades, "a continuation of lifelong learning will be more important than ever, not solely on grounds of principle, but for the pragmatic reason that we are entering an era in which no individual can count on having completed his or her formal education" (p. 27).

President Kenny's reports unfailingly expressed strong support for continuing education activities at UBC. During most of Kenny's years as UBC 
president, Jindra Kulich served as the director of Continuing Education. In Kulich's 1975-76 annual report, he celebrated the 40th anniversary of the establishment of the Department of University Extension:

The Centre is proud of its past and ready and willing to continue to serve the University and the community in the years to come. In this it will have to rely on continuing support from the University administration, cooperation of faculties and individual faculty members, and dedication of its professional, secretarial and support staff, as well as positive response to its programs from the community. (p. 1)

In his report for 1977-78, Kulich expressed a renewed commitment to the civic, liberal, and professional pillars of education that had been elaborated by his predecessors. He wrote that in a "modern diverse society, continuing education must provide a mosaic of opportunities for adults to better cope with the major roles they play. Among these roles are those of the professional or employee, the family member and citizen, and the individual" (p. 1).

In 1978-79, Kulich's staff unanimously adopted a "Statement of Roles and Goals for the Centre for Continuing Education." He cited the following passage from that statement in his annual report:

Since the citizens, organizations and institutions of British Columbia have become increasingly aware that learning is an important ingredient in their lifelong growth and development, their demands and needs for continuing education programs and services are growing and changing. To a greater extent than ever before, they also realize that they must have access to a variety of learning resources available in the province if they are to participate effectively in influencing the social, economic and political forces that govern their lives. Thus in fulfilling its provincial mandate, the Centre for Continuing Education must develop and deliver programs and services which integrate responsiveness to the needs and circumstances of adult learners and accessibility to learning resources ... (pp. 2-3)

The annual reports of Kenny and Kulich demonstrated both a renewal of more positive relationships between the Centre for Continuing Education and senior administration and a more expansive extension function at UBC.

\section{Conclusions}

This article has narrated the ebb and flow of presidential support for extension and continuing education at UBC from 1935 through 1983. Over these years, UBC directors of extension and continuing education either aligned themselves with the words of their presidents or struggled to position their units in response to unwelcome words from those presidents. This case 
study has both inherent and instrumental value for CJUCE readers. It is, in its own right, an interesting study of the history and philosophy of extension and continuing education at one of Canada's largest universities. It demonstrates that, beyond "legend and lore," it is possible to explore the influence of senior administrators on university continuing education units. For those without an interest in history and philosophy, this case study has two very practical and contemporary implications.

First, it is important to understand that university presidents do not act freely; they are as constrained by social and institutional forces as anyone else. President Klinck did not establish an extension department because he was a nice guy or because he just thought it would be a good idea. He did so because his university was struggling with crushing budgetary cutbacks and an absence of public support with which to confront the government responsible for making such cutbacks in an era of economic recession. University extension, initially funded through an external grant, was seen as an effective strategy to enhance public support for UBC. President Macdonald did not marginalize the Extension department because he was evil or stupid. Faced with intense enrolment and resource pressures, he made a strategic decision to distinguish UBC from a host of other, emerging post-secondary institutions through an emphasis on research and graduate and professional education. Likewise, the discourse of MacKenzie and Kenny must also be understood in light of their respective circumstances: the expansion of public investment in universities in the postwar period, and the stagnation in enrolments and government funding of the 1970s. For today's continuing education leaders, the lesson from this conclusion is that we must do more than simply be on good terms with our senior administrators. We must understand the social and institutional forces that constrain those administrators, and we must help those administrators understand how extension and continuing education contribute productively to university and society in the contemporary context.

Second, leaders in continuing education have the opportunity to align themselves with, and to influence the direction of, broader university discourse. Directors Shrum and Friesen did not simply read the reports and follow the advice of their presidents, Klinck and MacKenzie. They actively shaped the content of the annual president's report by submitting their own annual reports. Similarly, directors Friesen and Selman did not simply read President Macdonald's reports and give up on university extension. They found ways to adapt their department's activities to the constraints and opportunities presented in the 1960s. Friesen and colleagues obtained significant external grant funding to maintain an ambitious and diverse extension program. Selman advocated for a renewal of institutional commitment to continuing education; his advocacy was met, perhaps coincidentally, with 
the appointment of a president who for nearly a decade championed such commitment. For today's continuing education leaders, the lesson from this conclusion is that we must take advantage of sympathetic forms of contemporary institutional discourse (e.g., university-community engagement) and find ways of nurturing a positive relationship with less sympathetic forms (e.g., research intensity). We must align our units with institutional priorities, while advocating for the development of priorities that reflect our values and commitments. Furthermore, since many senior administrators have limited knowledge of university continuing education, we must be prepared to educate them and even to write passages for their reports and speeches.

This article provides no blueprint for working with senior administrators to promote the interests of continuing education at Canadian universities. However, it does give an interesting historical illustration of the importance of this relationship, and it does provide a foundation for reflection by those wishing to nurture the best possible relationships with presidents and provosts.

\section{References}

Alexander, A. (1997). The Antigonish movement: Moses Coady and adult education today. Toronto: Thompson Educational Publishing.

Association of Universities and Colleges of Canada (AUCC). (2009). Our universities. Ottawa, ON: Author. Retrieved August 19, 2009, from http:// www.aucc.ca/can_uni/our_universities/index_e.html.

Canada, Dominion Bureau of Statistics (DBS). (1941). Eighth census of Canada, 1941. Ottawa, ON: King's Printer.

Canada, Dominion Bureau of Statistics (DBS). (1951). Ninth census of Canada, 1951. Ottawa, ON: King's Printer.

Clark, R. (1985). A history of the Department of Extension at the University of Alberta, 1912-1956. Unpublished PhD dissertation, University of Toronto, Toronto, Ontario.

Corbett, E. (1952). University extension in Canada. Toronto: Canadian Association for Adult Education.

Cormack, B. (1981). Beyond the classroom: The first 60 years of the University of Alberta Department of Extension. Edmonton: University of Alberta, Faculty of Extension.

Kidd, J. (1956). Adult education in the Canadian university. Toronto: Canadian Association for Adult Education. 
Klinck, L. (1935, November). A plan for adult education in British Columbia. An address presented to the meeting of the Vancouver Institute, Vancouver, BC. (Document available in UBC Archives.)

Macdonald, J. (1962). Higher education in British Columbia and a plan for the future. Vancouver: UBC.

McLean, S. (2007a). University extension and social change: Positioning a "University of the People" in Saskatchewan. Adult Education Quarterly, 58(1), 3-21.

McLean, S. (2007b). "A Work Second to None": Positioning extension at the University of Alberta, 1912-1975. Studies in the Education of Adults, 39(1), 77-91.

McLean, S. (2008). Extending resources, fostering progress, or meeting needs? University extension and continuing education in western Canada. British Journal of Sociology of Education, 29(1), 91-103.

Paul, L. (1979). Extension at the University of Saskatchewan, Saskatoon, 1910-70: A history. Saskatoon: University of Saskatchewan Press.

Selman, G. (1966). A history of fifty years of extension service by the University of British Columbia. Toronto: Canadian Association for Adult Education.

Selman, G. (1988). The invisible giant: A history of adult education in British Columbia. Vancouver: UBC, Centre for Continuing Education.

Statistics Canada. (1971). 1971 census of Canada. Ottawa, ON: Author.

University of British Columbia (UBC). (1915). Calendar of the University of British Columbia: First session, 1915-16. Vancouver: Author.

University of British Columbia (UBC). (2009). UBC student enrolment figures, 1915-present. Vancouver: Author. Retrieved August 19, 2009, from http://www.library.ubc.ca/archives/enrolmnt.html.

Welton, M. (2003). Pioneers and progressive pedagogues: Carrying the university to the people of Saskatchewan, 1905-1928. Canadian Journal for the Study of Adult Education, 17(2), 59-83. 


\section{BIOGRAPHY}

Scott McLean is the director of Continuing Education at the University of Calgary. His work has ranged from teaching adult basic education to developing university extension programs in agricultural leadership and health promotion. Scott has published widely on and taught graduate courses in the field of adult and continuing education.

Scott McLean est directeur de l'éducation permanente à l'Université de Calgary. Son travail a varié de l'enseignement de l'éducation de base aux adultes au développement de programmes universitaires d'extension en leadership agricole et en promotion de la santé. Scott a plusieurs publications à son nom et a enseigné des cours de deuxième cycle dans le domaine de l'éducation aux adultes et de l'éducation permanente. 